\title{
In Vitro Establishment and Epiphyllous Plantlet Regeneration of Nymphaea 'Daubeniana'
}

\author{
Matthew Jenks, Michael Kane, Francis Marousky, \\ Dennis McConnell, and Thomas Sheehan \\ Department of Environmental Horticulture, IFAS, University of Florida, \\ Gainesville, FL 32611
}

Additional index words. tissue culture, aquatic plants, water lily, micropropagation

Water lilies (Nymphaea spp.) are the most popular water garden plants but are expensive to propagate. Traditional vegetative propagation techniques are inefficient, and losses to disease also contribute to the high costs. In vitro propagation of disease-free stock may be an effective method for combating disease losses, reducing propagation costs, and facilitating long-term germplasm storage. We found no published reports of establishment and multiplication of $\mathrm{Nym}$ phaea species in vitro. However, in vitro establishment of Nelumbo lutea, another member of the Nymphaeaceae, suggests that Nymphaea species may respond to in vitro propagation techniques (Kane et al., 1988). We found this to be the case for the tropical water lily Nymphaea 'Daubeniana' Hort. ex O. Thomas, which is described herein.

Nymphaea 'Daubeniana', a sterile hybrid, reproduces asexually in situ via formation of epiphyllous plantlets from the adaxial surface of floating leaves above the point of petiole insertion (Masters, 1974). Leaves bearing immature plantlets 3 to $4 \mathrm{~mm}$ long were collected from plants maintained in tanks in a greenhouse. Epiphyllous plantlets were excised from donor leaves leaving a 3-mm"diameter ring of leaf tissue surrounding the base of each plantlet. Explants were rinsed in flowing tap water for $30 \mathrm{~min}$. The trichomes were removed and the explants were again rinsed for $30 \mathrm{~min}$ in tap water followed by immersion in $50 \%(\mathrm{v} / \mathrm{v})$ ethanol for 90 sec and a 5-min rinse in sterile deionized water. Explants were agitated in $1.31 \%$ $(\mathrm{v} / \mathrm{v})$ aqueous sodium hypochlorite containing two drops of Tween-20 per $100 \mathrm{ml}$ for $12 \mathrm{~min}$ followed by three successive 5-min rinses in sterile deionized water. Explants were individually transferred into $150 \times 25$ $\mathrm{mm}$ culture tubes and cultured submersed in

Received for publication 27 Apr. 1990. Fla. Expt. Sta. J. Ser. no. R-00651. Funds provided in part by the Division of Marketing, Florida Dept. of Agriculture and Consumer Services and the IFAS Center For Natural Resources. The cost of publishing this paper was defrayed in part by the payment of page charges. Under postal regulations, this paper therefore must be hereby marked $a d$ vertisement solely to indicate this fact.
$12 \mathrm{ml}$ liquid basal medium (BM) consisting of Murashige and Skoog (1962) inorganic salts with $87.6 \mathrm{~mm}$ sucrose, $0.56 \mathrm{~mm}$ myoinositol, and $1.2 \mu \mathrm{M}$ thiamine- $\mathrm{HCl}$ supplemented with $10 \mu \mathrm{M}$ isopentenyladenine (2iP) and $3 \mu \mathrm{M}$ indole-3-acetic acid (IAA). The medium was adjusted to $\mathrm{pH} 5.7$ with $0.1 \mathrm{~N}$ $\mathrm{KOH}$ before being autoclaved at $1.2 \mathrm{~kg} \cdot \mathrm{cm}^{-2}$ for $20 \mathrm{~min}$ at $121 \mathrm{C}$. All cultures were maintained at $25 \pm 2 \mathrm{C}$ under a 16 -hr photoperiod provided by cool-white fluorescent tubes at $50 \mu \mathrm{mol} \cdot \mathrm{s}^{-1} \cdot \mathrm{m}^{-2}$. Histological sectioning and scanning electron microscopy procedures followed those outlined by Broschat et al. (1989) and Marousky and West (1990), respectively.

Sixteen cultures were established using this surface sterilization procedure. The established explants, cultured for 5 weeks in liquid $\mathrm{BM}$ with $10 \mu \mathrm{M} 2 \mathrm{iP}$ and $3 \mu \mathrm{M}$ IAA, remained unbranched and produced noncutinized, highly vitrified leaves without epiphyllous plantlet formation. Plantlets subsequently transferred to the same medium solidified with $0.8 \%$ (w/v) TC Agar (Hazleton Research Products, Lenexa, Kan.) for 4 weeks grew slowly, remained unbranched, and produced cutinized nonvitrified leaves without epiphyllous plantlets. Plantlets were subcultured for 5 weeks on $53 \times 53-\mathrm{mm}$ polypropylene membrane rafts (Sigma, St. Louis) floated in $7.5 \times 7.5 \times 10-\mathrm{cm} \mathrm{Ma-}$ genta GA-7 Vessels (Magenta Corp., Chicago) containing $80 \mathrm{ml}$ of $\mathrm{BM}$ with the exception that $3 \mu \mathrm{M}$ thidiazuron $(N$ - phenyl$N^{\prime}$-1,2,3-thiadiazol-5-ylurea; $98 \%$ a.i., NORAM Chem. Co., Wilmington, Del.) was substituted for $2 \mathrm{iP}$. Of 16 plantlets subcultured on membrane rafts for 5 weeks, 12 plants produced an average of eight nonvitrified cutinized aerial leaves (Fig. 1A) each bearing a single epiphyllous plantlet in the same position and adaxial orientation (Fig. $1 \mathrm{~B}, \mathrm{C}$ ) as those produced in situ (Masters, 1974).

Presently, the physiological mechanism(s) regulating epiphyllous plantlet development in tropical water lilies is unknown. In vitro culture provides an ideal system to further optimize the environmental and hormonal factors regulating plantlet regeneration and ultimately should serve as a method for clonal propagation.

\section{Literature Cited}

Broschat, T.K., H. Donselman, and D.B. McConnell. 1989. Light acclimatization in Ptychosperma elegans. HortScience 24:267-268.

Kane, M.E., T.J. Sheehan, and F.H. Ferwerda. 1988. In vitro growth of American Lotus embryos. HortScience 23:611-613.

Marousky, F.J. and S.H. West. 1990. Somatic embryogenesis and plant regeneration from cultured mature caryopses of bahiagrass (Paspalum notatum Flugge). Plant Cell Tissue Organ Culture 20:125-129.

Masters, C.O. 1974. Encyclopedia of the waterlily. T.F.H., Neptune City, N.J.

Murashige, T. and F. Skoog. 1962. A revised medium for rapid growth and bioassays with tobacco tissue cultures. Physiol. Plant. 15:473497.

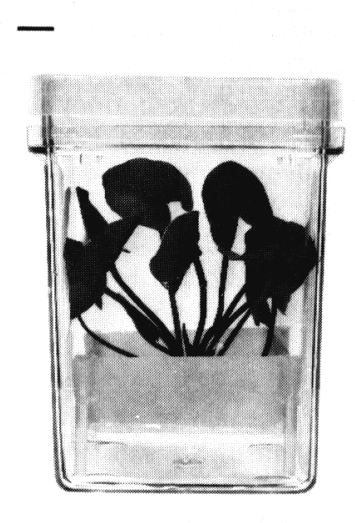

A

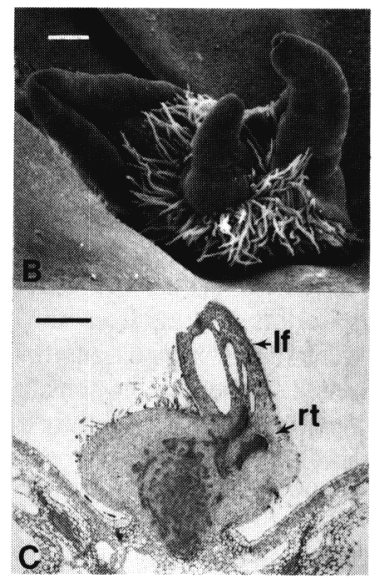

Fig. 1. Epiphyllous plantlet formation of Nymphaea 'Daubeniana'. (A) Established plant producing epiphyllous plantlets after 5 weeks of culture on a polypropylene membrane raft floated on liquid basal medium with $3 \mu \mathrm{M}$ thidiazuron and IAA. Bar $=1.0 \mathrm{~cm}$. (B) Scanning electron micrograph of an in vitro epiphyllous plantlet. Bar $=250 \mu \mathrm{m}$. (C) Median longitudinal section of an epiphyllous plantlet depicting early leaf (lf) and root (rt) development. Bar $=250 \mu \mathrm{m}$. 